\title{
CARACTERIZAÇÃO DOS AREAIS DA BACIA DO RIBEIRÃO SUJO, MUNICÍPIO DE SERRANÓPOLIS/GO ${ }^{1}$
}

\author{
Marluce Silva Sousa*
}

\section{RESUMO:}

A microbacia do Ribeirão Sujo, bacia do Paranaíba, abrange uma área de $164 \mathrm{~km}^{2}$ no município de Serranópolis, na microrregião Sudoeste de Goiás, apresentando extensas manchas de solos arenosos degradados e sem cobertura vegetal, chamados de "areais". Nesta microbacia foram analisados os condicionantes naturais e as transformações da paisagem pelos processos sociais para compreender a formação dos areais. O objetivo deste trabalho é apresentar os principais aspectos dos areais, com ênfase na compreensão do nível de degradação do solo. O processo de formação de areais envolve uma dinâmica que se desencadeou a partir da carência de nutrientes e do manejo inadequado do solo numa área de forte fragilidade potencial, originando pequenas manchas de areia exposta, desencadeando processos erosivos e degradação do solo, associados à excessiva pressão de pastejo, o que, por sua vez, facilitou a expansão dos areais. A dimensão dos areais já perfaz $1,4 \%$ da área da microbacia, tendo o maior deles cerca de 79 ha. Sugere-se, de imediato, a implantação de medidas mitigadoras para conter o avanço dos areais e, com tempo, a sua possível recuperação.

PALAVRAS-CHAVE:

Cerrado; Fragilidade ambiental; Uso e manejo do solo; Areais.

\begin{abstract}
:
SANDY SPOTS CHARACTERIZATION ON THE "RIBEIRÃO SUJO" WATERSHED, AT SERRANÓPOLIS MUNICIPALITY/GO

The "Ribeirão Sujo" watershed belongs to the "Paranaíba" basin and encloses an area of 164 square kilometers, inside Serranópolis municipality, into the southwest micro region of Goiás state (Brazil), which features extensive spots of degraded sandy soils, called "sandy spots". The natural circumstances and landscape transformations by the social processes was analyzed in order to understand these sandy spots development. The objective of this work is to present the main aspects of the sandy spots, emphasizing the understanding of soil level degradation. The dynamic that explain the sandy spots growth process is related to the lack of fertility and improper soil management in an area of high potential fragility, originating small sand spots, with the beginning of erosive processes and soil degradation. The relative excess of pasture-pressure facilitates the sandy spots expansion. The sandy spots extension already covers $1.4 \%$ of the watershed area, where the greatest spot reaches approximately 79 ha. It's suggested, immediately, the implementation of mitigating measures in order to restrain the sandy spots advancement and, in the future, the possibility of their recovering.
\end{abstract}

\section{KEY WORDS:}

Cerrado in Brazil; soil use and management; sandy spots; sandization. 


\section{Introdução}

A formação de areais no Sudoeste de Goiás vem sendo pesquisada desde 2002, especificamente no município de Serranópolis, onde ocorre um intenso processo de degradação ambiental, cuja maior expressão é a presença de ravinas, voçorocas e areais que têm levado à degradação do solo, da água e ao assoreamento dos cursos d'água. Foi constatado que esse processo não ocorre nos mesmos moldes daqueles do Rio Grande do Sul, onde foi denominado "arenização", isto é, "retrabalhamento de depósitos areníticos (poucos consolidados) ou arenosos (não consolidados), que promove, nessas áreas, uma dificuldade de fixação de vegetação, devido à constante movimentação de sedimentos". (SUERTEGARAY, 1996, p. 254).

Apesar da gravidade do problema, são recentes os estudos técnicos e científicos em escala apropriada, no Sudoeste de Goiás, dificultando o conhecimento detalhado dos problemas e a possibilidade de intervenção. Assim, a caracterização do meio físico, a definição de indicadores que possam auxiliar na avaliação de terras em relação à degradação, o monitoramento das mudanças de uso da terra e da qualidade ambiental, e a análise da degradação do solo poderão fornecer subsídios ao planejamento de uso da terra por parte dos administradores e proprietários de terras de Serranópolis. Neste sentido, o objetivo deste trabalho é caracterizar os areais da bacia do Ribeirão Sujo, com ênfase na compreensão do seu nível de degradação do solo.

O Ribeirão Sujo é afluente da margem direita do Rio Verde que, por sua vez, é afluente do Rio Paranaíba. Sua microbacia, de terceira ordem, abrange uma área de $164 \mathrm{~km}^{2}$ no município de Serranópolis, na microrregião Sudoeste de Goiás. A área abriga lavouras de cana-de-açúcar, de soja, pastagens e remanescentes da vegetação original de cerrado.

A microbacia hidrográfica do Ribeirão Sujo, cuja localização pode ser observada na Figura 1, será referida no texto, abreviadamente, como $\mathrm{MH}$ Ribeirão Sujo.

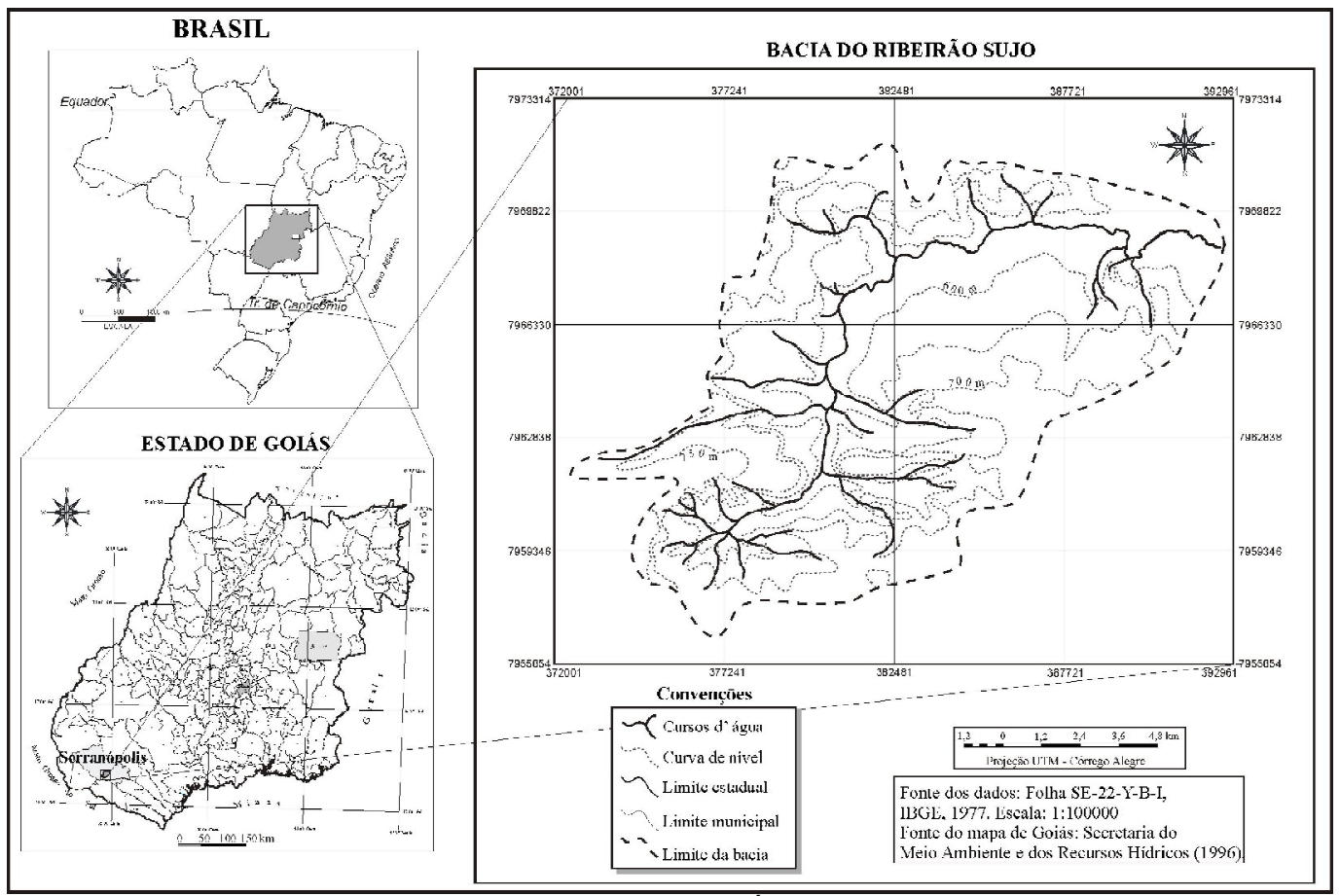

Figura 1 - Localização da área de estudo 
Feições comuns na MH Ribeirão Sujo, os areais são manchas ${ }^{2}$ de Neossolos Quartzarênicos sem ou com rara cobertura vegetal, expostos a ações erosivas e resultantes da degradação do solo in situ e/ou da deposição de areia transportada (SOUSA, 2007). Caracterizam-se, sobretudo, pelo alto nível de degradação em relação às condições morfológicas, físicas, químicas e biológicas dos solos em estado original. Ocupam 236 ha, o que representa 1,4\% da bacia do Ribeirão Sujo (Figura 2), encontrando-se distribuídos por quatro manchas principais, concentradas em áreas que apresentam limitações muito fortes frente ao uso agropecuário intensivo, sendo consideradas de muito forte fragilidade potencial.

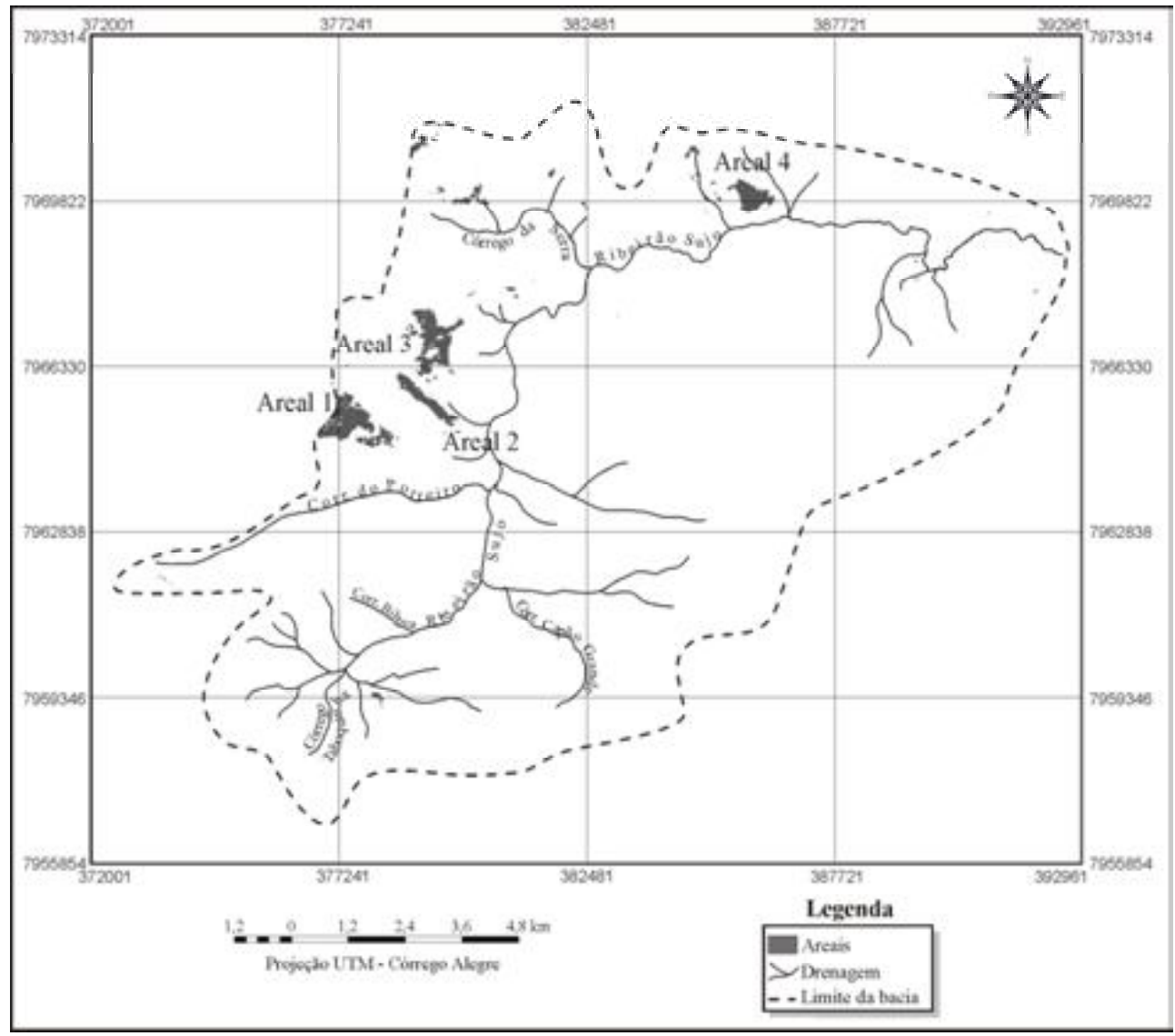

Figura 2 - Carta da distribuição dos areais na bacia do Ribeirão Sujo.

Esses areais ocupam diversas posições topográficas, com maior incidência em rampas convexas e, secundariamente, rampas côncavas e topos. Atualmente, observa-se nos areais a ocorrência de erosão laminar e, secundariamente, de erosão linear e eólica.
Os areais da MH Ribeirão Sujo são formas recentes na paisagem, conseqüentes de processo socioeconômico que passa pelo cultivo da canade-açúcar, por um ou mais ciclos, seguido pelo de braquiária, como decorrência da incorporação dos solos menos produtivos ou mais pobres do 
município de Serranópolis à "modernização da agricultura, "implantada na década de 1980 . Situam-se numa propriedade de cerca de $14 \mathrm{mil}$ ha e encontram-se abandonados há aproximadamente quatro anos, integrando, desde então, áreas que não estão sendo utilizadas sequer como pastagem.

\section{Procedimentos operacionais}

Várias etapas foram desenvolvidas na realização do trabalho. Iniciou-se pela revisão bibliográfica e levantamento cartográfico. Elaborou-se uma base de dados em formato digital no Spring 4.2, utilizando a carta topográfica SE 22 YB IV, escala 1:100.000 (IBGE, 1977) como carta-base, a partir da qual foram geradas as cartas de Hipsometria e Declividade. Da interpretação das fotografias aéreas verticais, na escala 1:60.000 (USAF, 1965 ) resultaram as cartas de geologia, morfologia do relevo, solos e vegetação (SOUSA, 2007).

Para o mapeamento do uso atual da terra e dos areais foi utilizada a composição colorida 2B3R4G do CCD/CBERS, fornecidas pelo INPE, com $20 \mathrm{~m}$ de resolução espacial e datada de 24 de março de 2004. Após vários testes, utilizouse classificação supervisionada, empregandose Maxver, para o mapeamento dos areais.

Para determinar a degradação do solo, além das observações in loco, seguiram-se as indicações da literatura revisada e foram coletadas amostras nos quatro principais areais da bacia do Ribeirão Sujo, bem como numa área de cerrado que possuía semelhantes condições geológicas e pedológicas. Coletaram-se as amostras do solo sob cerrado, sentido restrito típico, como referência, para efeitos de comparação das análises, considerando-as como estando o solo em estado natural e com potencial edáfico, em equilíbrio na relação soloplanta, tal como recomendam Dias e Griffith (1998). As análises foram feitas, conforme metodologia preconizada pela Embrapa (1997), pelo laboratório de análises de solos do Campus Jataí/UFG. Realizaram-se as seguintes análises: granulometria, $\mathrm{pH}$ em água, matéria orgânica, $\mathrm{P}, \mathrm{K}, \mathrm{Ca}, \mathrm{Mg}, \mathrm{H}+\mathrm{Al}, \mathrm{Al}$ e capacidade de troca de cátions a $\mathrm{pH} 7,0$.

Trabalhos de campo foram realizados durante todas as etapas da pesquisa.

\section{Origem e evolução dos areais}

Os areais da MH Ribeirão Sujo são formas espaciais decorrentes de uma dinâmica recente da paisagem, sua origem envolvendo as condições de forte fragilidade dos elementos físico/ ecológicos, potencializada pelo uso e manejo da terra inadequados no decorrer das transformações da paisagem a partir da década de 1980.

Desse modo, pode-se apontar os fatores desencadeadores que, em maior ou menor grau, contribuem para a formação de areais:

a) Material de origem: os arenitos Botucatu.

A existência dos arenitos da Formação Botucatu é o primeiro condicionante da fragilidade potencial da área e, consequentemente, da formação dos areais. Tais rochas têm classe modal predominantemente de areia fina compondo-se de grãos de quartzo e, em menor quantidade, feldspato, fragmentos líticos e argila, apresentando características litológicas e sedimentares de deposição em ambiente desértico e alto grau de arredondamento dos grãos de areia (MENDES, 1984; PETRI; FÚLFARO, 1988). Caracterizam-se, ainda, pela presença de pouca matriz e estratificação cruzada de porte médio a grande, fatores que facilitam o direcionamento dos fluxos d'água em subsuperfície, a desagregação mecânica e a remoção dos grãos de quartzo. Os arenitos são encobertos por espesso manto intempérico ensejando a formação de solos extremamente profundos, como aqueles que caracterizam os areais.

Além disso, os arenitos da Formação Botucatu apresentam grande potencial de lixiviação dos poucos nutrientes (principalmente do K, liberado da sericita/muscovita) e, portanto, 
potencial químico muito baixo, dando origem a solos distróficos ou álicos.

b) Clima: precipitações mal distribuídas.

As contribuições climáticas para a formação dos areais, ainda pouco conhecidas, estão relacionadas às precipitações mal distribuídas durante o ano, característica do sudoeste de Goiás. Adiante será mostrado que a dinâmica climática atua em conjunto com a morfopedológica, desencadeando processos erosivos diferenciados nos períodos seco (abril a setembro) e chuvoso (outubro a março), promovendo a evolução dos areais.

Durante os seis meses de período seco a capacidade de água disponível para as plantas é muito baixa, o que é agravado pela alta porosidade dos Neossolos Quartzarênicos e, mesmo durante os meses chuvosos, verifica-se alta ocorrência de veranicos.

c) Relevo: vertentes longas suavizadas.

Considerando o relevo regional, os areais associam-se a uma depressão interplanáltica embutida no compartimento mais elevado do sudoeste de Goiás. A depressão interplanáltica do Rio Verde (SCOPEL, PEIXINHO, SOUSA, 2005) apresenta-se bastante dissecada relativamente às áreas circunvizinhas, originando formas convexas e, com menor expressão, tabulares nas quais predominam os arenitos da Formação Botucatu, encobertos por solos arenosos. Os ciclos de erosão pós-terciários promoveram a retirada dos sedimentos Terciários e Cretácicos, fazendo aflorar os arenitos Juro-cretácicos. Portanto, na área predominam processos de dissecação.

Quanto ao relevo local, os areais concentram-se na vertente esquerda do Ribeirão Sujo que apresenta rampas, em geral, longas, da ordem de $2 \mathrm{~km}$, em média, com formas variadas ao longo do seu segmento e ainda marcadas por rupturas positivas de declive com aumento nos valores de declividade nas áreas de menor altitude.

Quando os areais aparecem em segmentos côncavos, embaciados, nos quais o percentual de areia fina na sua composição é maior que a média, indicando que parte da areia é resultante de transporte, considera-se que a deposição de areia seja o fator principal de sua morfogênese. Entretanto, os areais predominam em vertentes convexas, ocupando várias posições, inclusive os topos, o que sugere que os areais resultem, principalmente, da evolução in situ das manhas iniciais.

d) Solos: Neossolos Quartzarênicos órticos (RQs).

A existência dos areais é condicionada por um único tipo de solo uma vez que, na própria definição, os "areais" são considerados Neossolos Quartzarênicos degradados. Os fatores inerentes aos RQs que condicionam a formação dos areais são: alto percentual de areia, em geral, mais de $90 \%$, muito profundos, grande capacidade de infiltração e movimentação da água em subsuperfície, assim como de lixiviação; baixa retenção de umidade e deficiência de água; baixa fertilidade natural (distróficos) e alta saturação por alumínio, sendo álicos em profundidade; baixos teores de matéria orgânica; esgotamento rápido com o uso agrícola; alta suscetibilidade à erosão e excessiva desagregação (friabilidade), ou seja, estrutura em grãos simples.

A associação entre este solo de alta friabilidade ao manejo inadequado é considerada o principal fator desencadeador dos areais, isto é: a degradação observada nos pelos RQs confunde-se com a própria formação dos areais. Por isso, foi investigado o seu nível de degradação em relação ao mesmo solo em condições originais.

Foram realizadas várias sondagens nos areais e alguns perfis são apresentados nas Figuras 3 e 4 . Nestes RQs, a diferenciação entre os horizontes ( $h$ ) A e C é extremamente sutil, sendo a transição entre eles geralmente gradual e ondulada, com pouca variação na textura. A cor ligeiramente mais escura no $h \mathrm{~A}$, devido aos maiores teores de matéria orgânica (MOS), relativamente ao $\mathrm{h} C$, foi observada em todos os perfis, ainda que o solo apresentasse alto teor de umidade. Em geral, o (horizonte) h Ap apresenta 25-30 cm de espessura, enquanto o h $\mathrm{C}$ tem início a $55-60 \mathrm{~cm}$ havendo, portanto, um horizonte de 
transição entre os dois. Observa-se uma camada superior no horizonte Ap, de cerca de $1 \mathrm{~cm}$, de cor mais clara e que, dada a rápida infiltração e evaporação, apresenta menor teor de água. O conjunto desses indícios favorece sua remobilização. A origem deste fenômeno será tratada adiante.

Figura 3 - Perfil de Neossolo Quartzarênico órticos típico situado no segmento superior da vertente; Areal 1

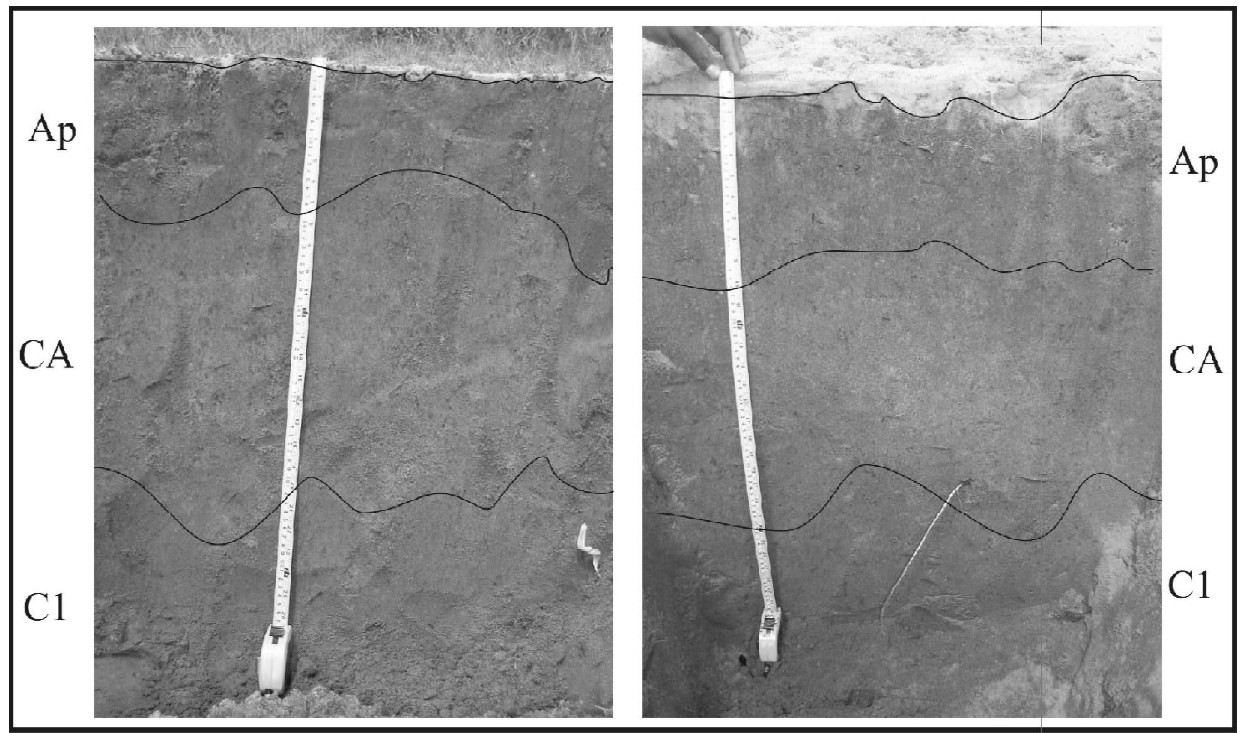

(Foto: $16 / 12 / 2006$ )

Figura 4 - Perfil em Neossolo Quartzarênico órticos típico no terço médio (duas primeiras fotografias) e inferior das vertentes no Areal 1

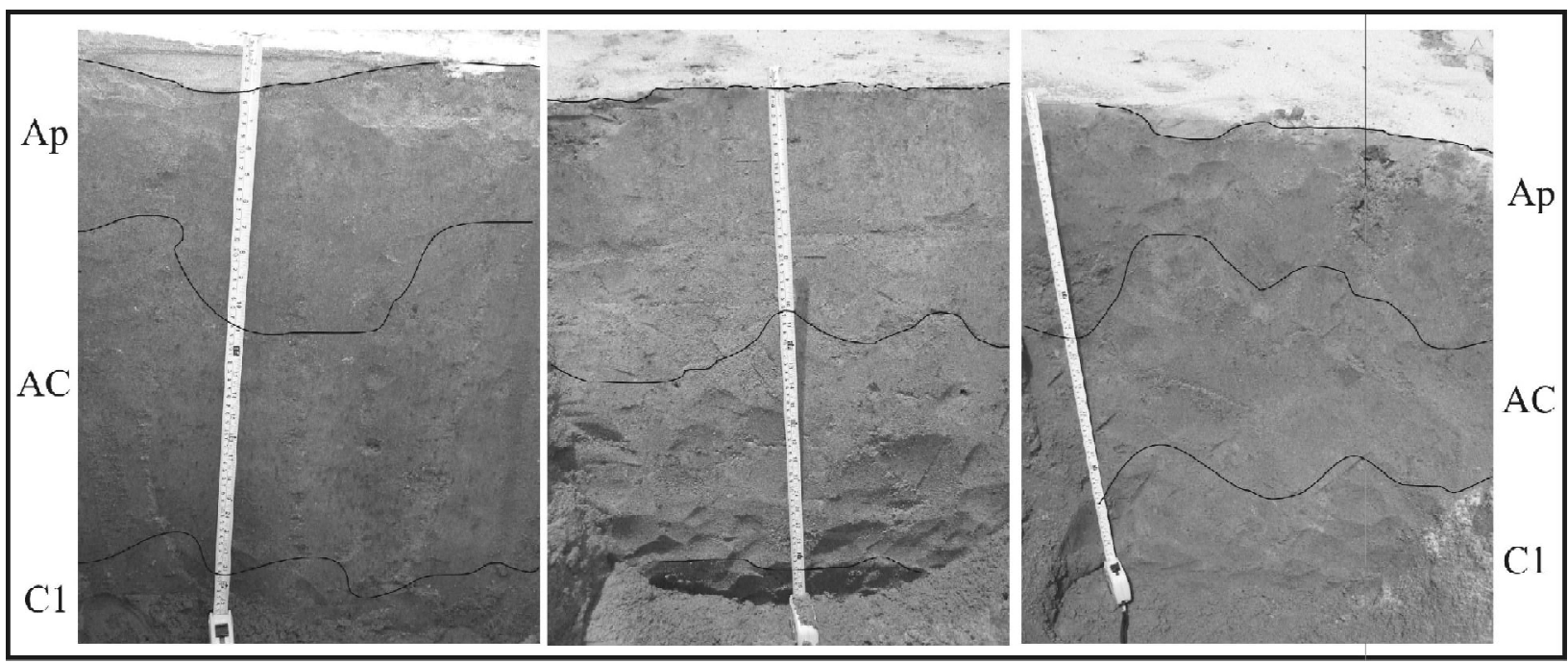

(Foto: $16 / 12 / 2006$ ) 
A interpretação conjunta dos resultados das análises de solo, nas principais manchas de areia, fornece importante contribuição à análise da degradação dessas áreas. São áreas visivelmente degradadas, com alterações nas características de solo e vegetação. Para Reinert (1998, p. 163) "a perda de condições desejáveis do solo, relacionadas ao crescimento de plantas e ambiente, tem sido considerada com DEGRADAÇÃo do solo". Ou "degradação do solo refere-se ao declínio da qualidade do solo, causado pelo mau uso humano (LAL; STUART, 1990 apud REINERT, 1998, p. 163). O mesmo autor divide a degradação em três tipos: física, química e biológica. Considerando os preceitos estabelecidos pelo autor, verifica-se os três tipos de degradação do solo nos areais, comprovados pelas seguintes características neles verificadas:

a) perda da pouca estabilidade (resistência dos agregados) da estrutura, originalmente fraca, do Neossolo Quartzarênico;

b) redução da matéria orgânica e da atividade e diversidade de organismos do solo e;

c) redução de nutrientes do solo, principalmente $\mathrm{Ca}, \mathrm{Mg}$ e $\mathrm{K}$, originalmente escassos.

Para analisar o nível de degradação do solo nos areais, compararam-se os resultados obtidos nas principais manchas com aqueles encontrados em cerrado original, como apresentado nos quadros 1 e 2 .

\section{Quadro 1 - Análise textural das amostras.}

\begin{tabular}{|cccccc|}
\hline Identificação & \multicolumn{5}{c|}{ Análise textu ral (\%) } \\
\cline { 2 - 5 } (Profundidade em cm) & Areia grossa & Areia fina & Areia total & Silte & Argila \\
\hline Area1 1:0 - 20 & 15,78 & 79,22 & 95 & 1 & 4 \\
Areal 1:60 - 80 & 15,51 & 79,49 & 95 & 1 & 4 \\
\hline Area1 2:0 - 20 & 21,20 & 73,80 & 95 & 1 & 4 \\
Areal 2:60 - 80 & 20,20 & 74,80 & 95 & 1 & 4 \\
\hline Area1 3:0 - 20 & 31,80 & 49,76 & 81 & 15 & 3 \\
Areal 3:60 - 80 & 37,71 & 47,34 & 85 & 11 & 4 \\
\hline Areal 4: $0-20$ & 6,18 & 88,71 & 95 & 1 & 4 \\
Areal 4:60 - 80 & 7,29 & 87,71 & 95 & 1 & 4 \\
\hline Cerrado: $0-20$ & 17,35 & 76,65 & 94 & 2 & 4 \\
Cerrado: $60-80$ & 17,93 & 76,07 & 94 & 2 & 4 \\
\hline
\end{tabular}

Em relação à análise textural, não existe grande discrepância entre os valores apresentados para as amostras dos areais. Todas as amostras, com exceção daquelas do Areal 3, apresentam mais de $90 \%$ de areia, muito pouco silte e argila. Os arenitos da Formação Botucatu têm classe modal predominantemente fina na área de estudo (PETRI; FÚLFARO, 1988), justificando o porquê dos RQs derivados desse arenito apresentarem maior quantidade de areia fina em comparação com a areia grossa, para todas as amostras. A mineralogia é composta essencialmente de quartzo, tal como a rocha de origem. São solos com muito baixa atividade elétrica na superfície dos seus constituintes (SCOPEL; PEIXINHO; SOUSA, 2005), confirmada pela baixa CTC, entre 1,7 e $3,9 \mathrm{Cmol}_{\mathrm{c}} / \mathrm{dm}^{3}$.

Não houve discrepância entre a composição granulométrica dos areais e aquela do solo sob cerrado, todas as amostras enquadrando-se na classe Neossolo Quartzarênico órtico típico.

Quanto aos aspectos químicos, os níveis de $\mathrm{Ca}, \mathrm{Mg}$, $\mathrm{K}$ e P, CTC, MOS, em geral, são baixos para todas as amostras. Os níveis de Al no solo 


\section{Quadro 2 - Análises químicas das amostras.}

\begin{tabular}{|c|c|c|c|c|c|c|c|c|c|c|c|c|c|}
\hline \multirow{2}{*}{$\begin{array}{c}\text { Identificação } \\
\text { (Profundidade } \\
\text { em cm) }\end{array}$} & \multirow{2}{*}{$\begin{array}{c}\mathrm{pH} \\
\left(\mathrm{CaCl}_{2}\right)\end{array}$} & \multicolumn{5}{|c|}{$\left(\right.$ Cmolc/dm $\left.{ }^{3}\right)$} & \multirow[b]{2}{*}{$\mathbf{K}$} & \multicolumn{2}{|c|}{$\left(\mathrm{mg} / \mathrm{dm}^{3}\right)$} & \multirow{2}{*}{$\begin{array}{c}\mathrm{g} / \mathrm{kg} \\
\text { MOS }\end{array}$} & \multirow{2}{*}{$\begin{array}{c}\begin{array}{c}(\text { Cmolc } \\
\left./ \mathrm{dm}^{3}\right)\end{array} \\
\text { CTC } \\
\end{array}$} & \multirow[b]{2}{*}{ V\% } & \multirow{2}{*}{$\begin{array}{l}\text { Sat. } \\
\text { Al\% }\end{array}$} \\
\hline & & $\mathrm{Ca}+\mathrm{M}$ & $\mathbf{C a}$ & Mg & Al & $\mathbf{H}+\mathbf{A l}$ & & $\mathbf{K}$ & $\mathbf{P}$ & & & & \\
\hline Areal 1: $0-20$ & 3,8 & 0,03 & 0,01 & 0,02 & 0,3 & 2,4 & 0,03 & 11,0 & 9,0 & 7,4 & 2,5 & 2,4 & 83 \\
\hline Areal 1: $60-80$ & 4,1 & 0,02 & 0,01 & 0,01 & 0,3 & 2,0 & 0,06 & 25,0 & 1,0 & 6,1 & 2,1 & 4,0 & 78 \\
\hline Areal 2: $0-20$ & 3,8 & 0,05 & 0,03 & 0,02 & 0,5 & 3,8 & 0,03 & 11,0 & 9,0 & 9,3 & 3,9 & 2,0 & 86 \\
\hline Areal 2: $60-80$ & 3,8 & 0,02 & 0,01 & 0,01 & 0,4 & 3,4 & 0,03 & 11,0 & 2,0 & 8,4 & 3,4 & 1,4 & 89 \\
\hline Areal 3: $0-20$ & 3,6 & 0,30 & 0,25 & 0,05 & 0,7 & 3,5 & 0,01 & 6,0 & 12,5 & 8,1 & 3,0 & 10,0 & 19 \\
\hline Areal 3: $60-80$ & 3,4 & 0,20 & 0,12 & 0,8 & 0,4 & 1,9 & 0,008 & 3,0 & 1,7 & 3,7 & 2,0 & 12,0 & 19 \\
\hline Areal 4: $0-20$ & 3,7 & 0,04 & 0,02 & 0,02 & 0,4 & 3,1 & 0,03 & 12,0 & 21,0 & 9,4 & 3,2 & 22 & 85 \\
\hline Areal 4: $60-80$ & 3,9 & 0,02 & 0,01 & 0,01 & 0,3 & 2,3 & 0,03 & 11,0 & 17,0 & 6,1 & 2,3 & 2,0 & 86 \\
\hline $\mathrm{Crd}^{*}: 0-20$ & 3,8 & 0,12 & 0,06 & 0,06 & 0,5 & 3,3 & 0,07 & 26,0 & 2,0 & 15,1 & 3,5 & 5,3 & 72 \\
\hline Crd.: 60 - 80 & 4,1 & 0,06 & 0,03 & 0,03 & 0,2 & 1,6 & 0,04 & 17,0 & 1,0 & 4,4 & 1,7 & 6,1 & 65 \\
\hline
\end{tabular}

*Vegetação original de cerrado.

variam de 0,2 a 0,7 $\mathrm{Cmol}_{\mathrm{c}} / \mathrm{dm}^{3}$, representando valores baixos. Entretanto, como os valores das bases são insignificantes, a CTC é, para todas as amostras, com exceção do Areal 3, ocupada em mais de $50 \%$ com este elemento, determinando seu caráter álico e limitante para as culturas, tendo em vista a toxidez que representa o Al para a maioria das plantas cultivadas.

O Areal 3 apresenta valores, no conteúdo de bases, superiores aos das demais manchas e, consequentemente, maior saturação por bases e menor por alumínio. Por outro lado, no Areal 2 o valor das bases é insignificante, a saturação por bases sendo a menor dentre os areais e a saturação com alumínio a maior, chegando este elemento a ocupar quase $90 \%$ da CTC.

Os areais 1 e 4 são aqueles que, de acordo com as análises, apresentam o maior nível de degradação, evidenciados pelos menores teores de bases e MOS. Todavia, os elevados valores, comparativamente, de $\mathrm{P}$ e de $\mathrm{K}$ são justificados pela adubação recebida no período em que foi cultivada a área e pela sutil mobilidade destes elementos no solo.

Quanto ao solo sob cerrado, verificou-se que possui níveis, no que tange à fertilidade, extremamente baixos, fato expresso pelo conteúdo de bases. Ainda assim, com exceção do $P$, foram os maiores valores comparativamente aos encontrados nos areais. A matéria orgânica (MOS) possui valores muito baixos sob vegetação, de 15,1 e $4,4 \mathrm{~g} / \mathrm{kg}$ para as duas profundidades amostradas, enquanto os valores de MOS nos areais foram extremamente baixos, para todas as amostras sendo sempre menores que $1 \%$. Nas amostras entre 0 e $20 \mathrm{~cm}$ de profundidade, representativa do horizonte superficial, a média apresentada pelos níveis de MOS nos areais é de $8,5 \mathrm{~g} / \mathrm{kg}$, valor que representa uma diminuição de $44 \%$ na matéria orgânica em relação ao nível encontrado sob cerrado nesta mesma profundidade. Disso pode-se inferir a degradação biológica, já que a matéria orgânica alimenta os microorganismos, que desempenham papel importante na nutrição das plantas, a degradação física, pois ela auxilia na agregação, na permeabilidade, na porosidade e na retenção de água e, por fim, a degradação química, uma vez que a matéria orgânica tem nutrientes e alta CTC que, por sua vez, atua na adsorção dos nutrientes.

Por outro lado, as taxas de infiltração, muito rápidas nos $R Q$, > $254 \mathrm{~mm} / \mathrm{h}$ (KOHNKE, 1968 apud SCOPEL; PEIXINHO; SOUSA, 2005) 
confirmam, para esses solos, a baixa retenção e permanência de água no perfil e, portanto, a baixa capacidade de água disponível. A partir dessa constatação, conclui-se que o solo degradado torna-se um ambiente sem sustentabilidade para o crescimento das plantas.

Pelo fato das áreas onde se encontram os areais terem sido fertilizadas, às vezes, os teores de $P$ e $K$ são um pouco mais altos, do que à adubação. Ainda assim, os níveis encontrados sob o cerrado, com exceção do P, são os maiores dentre os amostrados. Os valores de $\mathrm{P}$ superiores àqueles encontrados no cerrado são atribuídos à adubação e a pouca mobilidade deste nutriente no sistema. Portanto, considerando-se que as áreas foram adubadas, a retirada de nutrientes foi expressiva, evidenciando a degradação química dos solos nos areais.

e) Uso e manejo da terra

A vegetação original da vertente esquerda da MH Ribeirão Sujo era caracterizada por baixa densidade, em comparação com áreas próximas que apresentavam cerrado denso, o que demonstra a dificuldade natural de fixação e adensamento da vegetação. Todavia, em seu sistema natural, a vegetação original, embora rala, mantinha a proteção natural, interceptando as precipitações, fornecendo detritos vegetais e matéria orgânica ao solo, bem como auxiliando na sua estruturação através do fornecimento da matéria orgânica.

As raízes profundas, características das plantas do cerrado (FERRI, 1977), além de auxiliarem na estruturação do solo, compensavam a deficiência hídrica do período seco por meio da possibilidade de abastecimento da água reservada no solo. Observou-se que a camada superficial dos RQs, mesmo sob cerrado, possui estrutura fraca, condicionada, essencialmente, pela presença de raízes, como pode ser observado na Figura 5, bem como pela MOS, constantemente reposta pela camada de serrapilheira que é fornecida pela vegetação.

\section{Figura 5 - Raízes e serrapilheira em Neossolos Quartzarênicos sob cerrado (stricto sensu).}

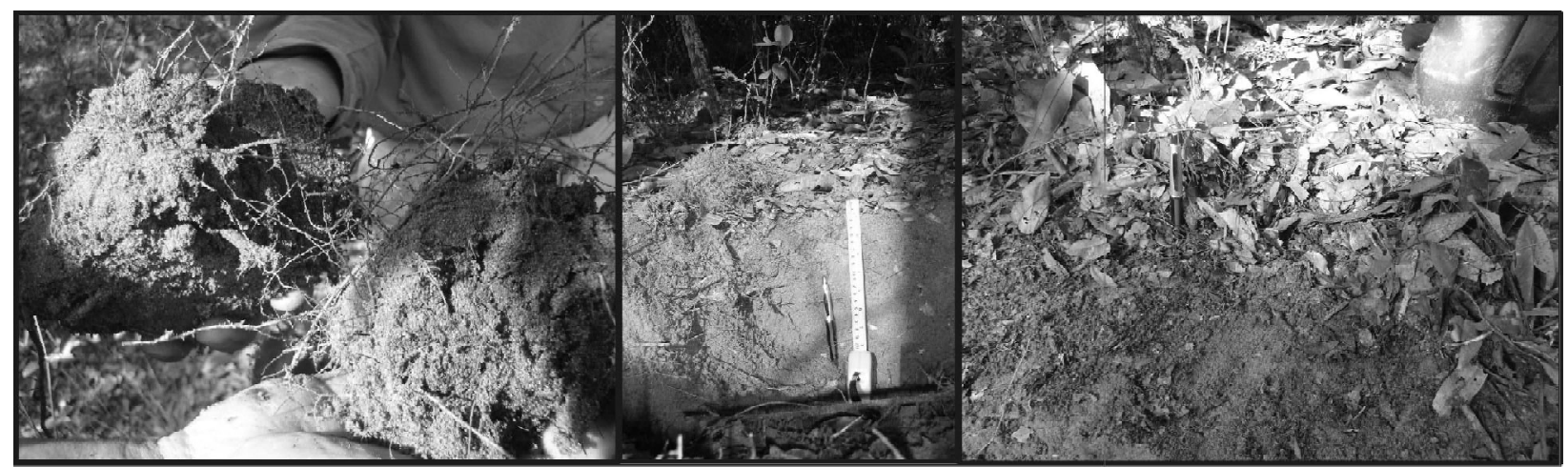

(Foto: $16 / 12 / 2006)$

A existência de vegetação possibilita a constante reposição de matéria orgânica no solo, que é benéfica de várias maneiras. Certas substâncias provenientes da decomposição dos restos orgânicos servem de "cimento" na formação dos agregados do solo, melhorando suas características físicas, notavelmente a permeabilidade, a porosidade e a retenção de água, além de alimentar os microorganismos que são importantes na nutrição das plantas. A matéria orgânica ajuda a evitar a desagregação e o deslocamento de partículas, evitando assim uma erosão pronunciada e diminuindo muito a possibilidade 
de rearranjo de partículas nas microdepressões (RESENDE，1985; LEPSCH, 2002).

O baixo nível técnico praticado pelos proprietários e dominante no Cerrado até o fim da década de 1970, como um todo, determinou que as áreas da $\mathrm{MH}$ Ribeirão Sujo, caracterizadas por grandes propriedades, fossem marginalizadas pelo processo produtivo local, ou subexploradas, com pecuária extensiva e manejadas com eventuais queimas, para o revigoramento da vegetação. Os produtores e proprietários de terra, embora sem o conhecimento técnico e científico, inferiam que a vegetação rala dos cerrados indicava a pobreza da terra, além da visível presença de areia no solo, de tal maneira que áreas assim caracterizadas não serviam para o cultivo das roças, tampouco para pastagens. Com isso, o preço das terras de cerrados ralos e campos sujos era muito inferior ao daquelas com campos limpos naturais, secos ou úmidos, e das "terras de cultura".

Esta situação permaneceu até o início da década de 1980, quando os baixos preços das terras arenosas de Serranópolis tornaram-nas atrativas para investidores de Araçatuba Companhia Rural Araçatuba/CRA - que adquiriram cerca de $14 \mathrm{mil}$ ha, área que abrange parte da MH Ribeirão Sujo e da bacia do Ribeirão das Pedras, ambos afluentes da margem direita do Rio Verde, com o objetivo inicial de investir na pecuária. Entretanto, atraídos pelos vultosos financiamentos e incentivos governamentais para a produção de álcool, os empresários planejaram e implantaram a empresa Goálcool - Destilaria Serranópolis Ltda.

A CRA desmatou as áreas em 1985, realizando a quebra da vegetação com correntão, enleiramento, queima e gradagem, sem a construção adequada de curvas de nível. O revolvimento da terra com arado é uma das atividades que rotineiramente é realizada pelos produtores e contribui para acelerar o processo de degradação do solo (LEPSCH, 2002). Se o desenvolvimento da atividade econômica primasse pelo conhecimento dos elementos naturais da paisagem, identificando a grande fragilidade potencial daquelas áreas, a implantação de curvas de nível e de outras práticas de manejo conservacionista deveria acontecer obrigatoriamente a fim de evitar o desencadeamento de problemas ambientais.

Apesar da ausência destas práticas, houve aplicação de fertilizantes de manutenção, com a mistura NPK, correção do solo com potássio, fosfatos e calagem, antes do plantio da cana-deaçúcar. De acordo com a explanação de Doorenbos e Kassan (1994), a cana-de-açúcar (Saccarum officinarum e outras quatro ou cinco espécies do mesmo gênero) desenvolve-se bem sob estação quente e longa com incidência de radiação alta e umidade relativa adequada, seguida de período seco, ensolarado e medianamente frio, porém sem geadas, durante a maturação e a colheita. Estas características, que favorecem o plantio da cultura, foram encontradas na bacia do Ribeirão Sujo. Além disso:

A cana-de-açúcar não necessita de um tipo especial de solo. Os melhores são aqueles com mais de $1 \mathrm{~m}$ de profundidade, embora seja possível ocorrer um enraizamento profundo de até $5 \mathrm{~m}$. O solo deve estar preferencialmente bem arejado (após uma chuva intensa, o espaço poroso cheio de ar é de 10 a 12\%) e possuir uma quantidade total de água disponível de $15 \%$ ou mais. Quando existe lençol freático, seu nível deve estar a uma profundidade além de 1,5 a 2,0 m da superfície. $\mathrm{O}$ pH ótimo do solo é em torno de 6,5, porém a cultura pode se desenvolver em solos com $\mathrm{pH}$ na faixa de 5 a 8,5 (DOORENBOS; KASSAN, 1994, p. 221).

Embora os Neossolos Quartzarênicos apresentem limitações referentes a quase todos os fatores limitantes no Sistema de Avaliação da Aptidão Agrícola das Terras, como grande deficiência de fertilidade, deficiência de água, suscetibilidade à erosão e impedimentos à mecanização, além das demais características dos elementos físicos que determinam a forte fragilidade potencial das áreas em destaque, a cana-de-açúcar, por ter uma enraizamento profundo e ser uma cultura perene, apresenta- 
se como uma daquelas que poderia trazer menor degradação à terra, comparativamente às culturas anuais. Todavia, as inúmeras limitações do solo e as exigências conservacionistas, a curto prazo, tendem a aumentar a demanda por investimentos, elevando os custos da produção.

Nas áreas foram plantadas inúmeras variedades de cana-de-açúcar, com destaque para a SP79 1011, por 5-6 anos, havendo 3 colheitas, com queima e corte manual, consequentemente relacionadas à intensa poluição atmosférica e ao trabalho exaustivo de centenas de "boias-frias". Durante este tempo não houve reaplicação de fertilizantes. De acordo com Spera et al. (2003), os RQ desgastam-se rapidamente com poucos anos de uso e necessitam de manejo planejado para continuar oferecendo condições à produção. A textura arenosa confere-lhes drenagem excessiva e pequena capacidade de retenção de água, favorecendo a lixiviação de nutrientes, especialmente do $\mathrm{N}$ e $\mathrm{K}$. Além disso, segundo Pasqualetto e Zito (2000), na produção da canade-açúcar é extraordinário o percentual de extração de $\mathrm{N}, \mathrm{P}, \mathrm{K}, \mathrm{Ca}, \mathrm{Mg}$ e $\mathrm{S}$, em ordem decrescente, confirmando o quanto a cultura é esgotante do solo. Do $\mathrm{N}$, em especial, nada retorna ao solo devido à queima da cana.

A necessidade de altos investimentos na produção, dadas as limitações dos Neossolos Quartzarênicos, associada à paralela diminuição dos subsídios do Proálcool, promoveu a decadência da GOálcool. A última colheita na área da vertente esquerda da $\mathrm{MH}$ foi realizada por volta de 1990 tendo, então, sido plantadas pastagens com Braquiária ssp.

Segundo Bertoni e Lombardi Neto (1999), as gramíneas, com sua densidade de hastes e sistema radicular, são adequadas ao controle da erosão, pois têm capacidade de diminuir a intensidade de enxurrada e prender as partículas do solo, contrapondo-se ao efeito da água, além de retardarem o seu movimento; atuam também no controle da erosão eólica, formando barreiras. Os autores destacam, ainda, que as gramíneas têm alta capacidade de resistir à seca, fator comum na área de pesquisa, vegetando em áreas de umidade limitada, e podem atuar na restauração da fertilidade do solo. Nesta perspectiva, Roscoe (2005) aponta que as pastagens bem manejadas são as principais fontes de armazenamento de carbono no Cerrado.

Entretanto, as pastagens implantadas na margem esquerda do Ribeirão Sujo, substituindo as lavouras de cana e assim como estas, não receberam o manejo adequado. Apesar do desgaste do solo provocado pela cultura da cana, a pastagem foi plantada sem qualquer aplicação de fertilizantes e práticas conservacionistas, como terraceamento e curvas de nível, de modo que em algumas áreas as sementes sequer chegaram a germinar, tendo início o desenvolvimento de pequenas manchas de areia descoberta. As pastagens foram arrendadas a pecuaristas, ou mesmo utilizadas pela CRA, aplicando-se uma pressão de pastejo acima da capacidade de suporte da pastagem, dando continuidade ao processo de degradação.

As evidências indicam que, com o tempo, tanto os nutrientes quanto a matéria orgânica do solo foram facilmente lixiviados, já que as sementes não brotaram, deixando o solo exposto. Além disso, muitas sementes que brotaram morreram devido ao calor excessivo do solo arenoso, justamente pela falta de água, fato que foi agravado pela ausência de árvores distribuídas pelas pastagens. A ausência de espécies nativas nestas áreas impossibilitou, também, a reposição, pelo menos em parte, da MOS, como acontecia no sistema natural.

Por volta de 1996, cinco anos após a implantação de pastagens, já apareciam claramente, na paisagem, manchas de areia. Os areais iniciais podem ter sido originados da não fixação da braquiária quando a pastagem, submetida ao superpastejo, pisoteio, à deficiência de nutrientes e de água na estação seca, somadas à falta de agregação das partículas do solo, carente de matéria orgânica, apresentou lastimável estágio de degradação.

g) Erosão e seu papel na formação e evolução dos areais

Como decorrência do manejo inadequado da terra, a fragilidade das áreas da vertente 
esquerda da $\mathrm{MH}$, relacionada aos elementos físicos, passou de potencial a ambiental (ROSS, 1994), desde que os processos potenciais foram desencadeados e se aceleraram como resultado da ação social da empresa, sedenta por lucros e financiada pelo Estado. O início da degradação das pastagens foi paralelo ao início da degradação do solo, já que os fatores de fragilidade continuaram a ser potencializados pelo manejo inadequado da terra. $\mathrm{Na}$ continuidade do processo, os primeiros focos de areia descoberta determinaram sua expansão areolar, ocasionada pela permanência do gado, perda da matéria orgânica, desagregação do solo e início de erosão laminar/ linear e eólica.

Sobre este aspecto vale ressaltar que, considerando os componentes predominantes na textura dos RQs, a areia fina possui grande facilidade em ser deslocada e transportada, enquanto a areia grossa pode sofrer alguma movimentação a curta distância, mas depositase com muita facilidade e tende a permanecer nessa superfície, dando-Ihe alguma proteção (RESENDE, 1985). Tais considerações indicam que os areais ocorrem:

- principalmente pela evolução in situ das manchas iniciais de exposição do solo, em áreas em que as sementes de gramíneas não germinaram ou morreram, devido ao calor excessivo, com expansão areolar devido ao constante pisoteio do gado e perda de partículas de solo, especialmente areia fina, silte e argila, por erosão laminar. Os areais resultantes posicionam-se ao longo de todo o segmento da vertente.

- secundariamente, por depósitos de areia transportada de áreas altimetricamente superiores. Neste caso, a camada superficial do solo no areal compõe-se, com maior percentagem do que no primeiro caso, de areia fina, posicionando-se nos terços médio e inferior das vertentes. Tratando-se de um fenômeno bastante recente (10 anos), a hipótese da ocorrência de areais, relacionada unicamente à deposição de sedimentos arenosos, não se sustenta.
Na Figura 6 aparece um areal em que podem ser apresentados os dois processos acima descritos. No topo a dinâmica se manifesta pela perda de material do horizonte superficial que se deposita na parte inferior, com contribuição de erosão linear. Estes processos não devem ser generalizados ao longo do segmento da vertente, pois os focos iniciais de areia descoberta ocorreram independentemente de sua posição. A erosão linear nem sempre está presente e pode ocorrer perda de sedimentos, também, na parte inferior da vertente. Além disso, é preciso considerar forma, declive e outras peculiaridades que se diferenciam ao longo do segmento de cada vertente e em cada areal.

É interessante ressaltar que a MH Ribeirão Sujo não apresenta significativa presença de incisões erosivas lineares, que são aquelas que, à primeira vista, parecem melhor representar a degradação ambiental. As alterações no solo e na vegetação, impostas pelas condições produtivas, são, portanto, mais significativas que a erosão, podendo-se afirmar que os areais não apresentam relação direta com a erosão linear. Todavia, pela ausência de cobertura vegetal, os areais tornam-se propícios ao desencadeamento de erosão laminar, linear e, inclusive eólica, como se pode observar nas Figuras 7 e 8 , processos que compõem a dinâmica atual dos areais e contribuem para agravar o estágio em que se encontram.

Na Figura 7, na primeira foto (Areal 3), observou-se que as constantes e fortes precipitações daquele dia não provocaram o desencadeamento de enxurradas e o escorrimento superficial, embora possa ser verificado, no apontamento das setas, o movimento superficial da água pluvial. Bastante porosos e permeáveis, os RQs tendem a absorver grande parte da água das chuvas apresentando grande capacidade de infiltração e movimentação da água em subsuperfície, fatos que, por sua vez, provocam o aumento da lixiviação dos nutrientes e perda da matéria orgânica, fatores prementes na gênese dos areais.

Percebe-se, ainda, o desenvolvimento de pequenas ondulações na camada superficial 
(Areal 1), por longas áreas em que não aparece qualquer vegetação, indicando início de atuação da erosão eólica. Já nas duas últimas fotografias observa-se sulcos de erosão em áreas côncavas (Areal 1) parcialmente preenchidos pela própria areia mobilizada.

Figura 6 - Exemplo de dinâmicas na formação de areais ao longo da vertente (Areal 4).

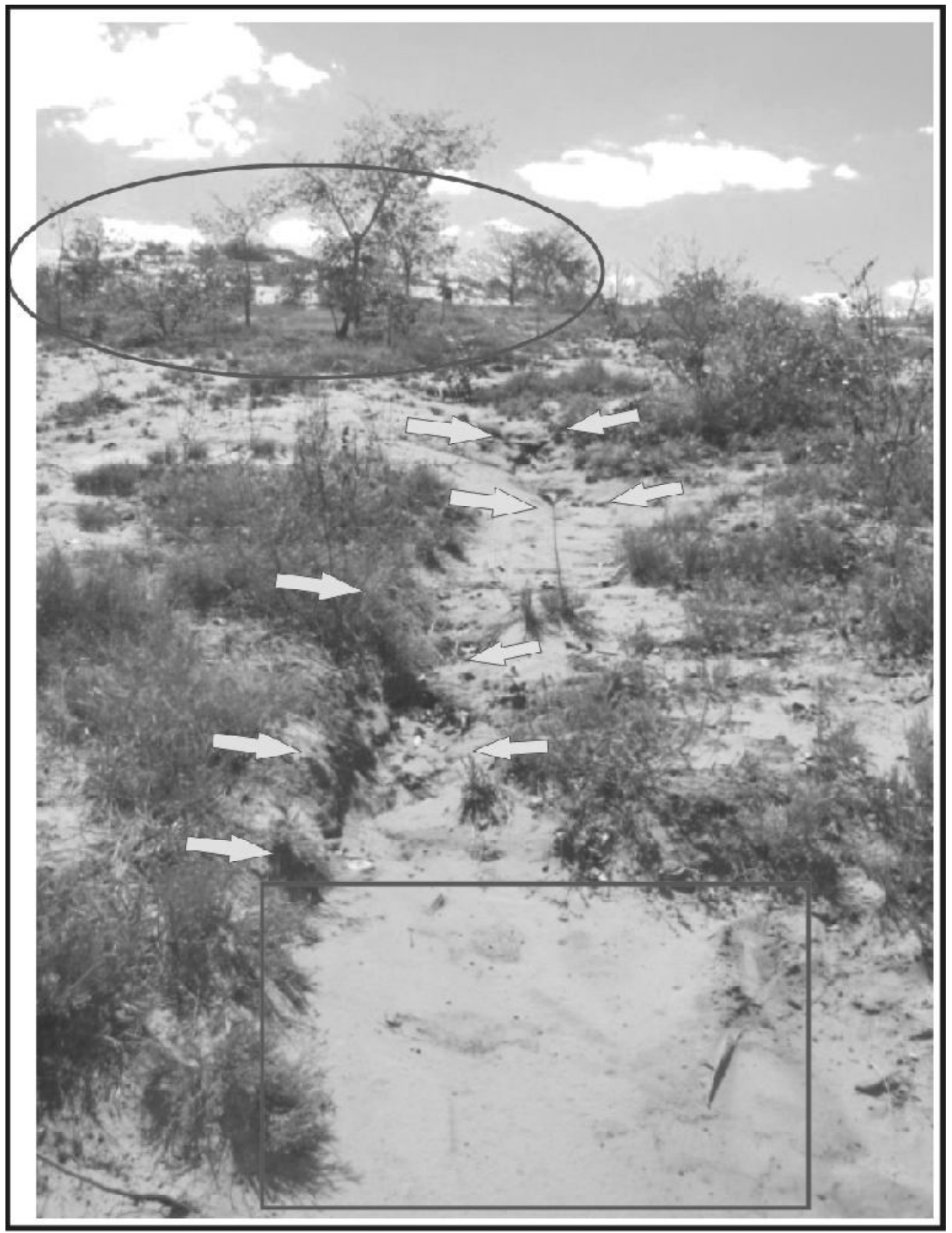

(Foto: 04/08/2006). 
Figura 7 - Ocorrência de erosão laminar, eólica e linear nos areais

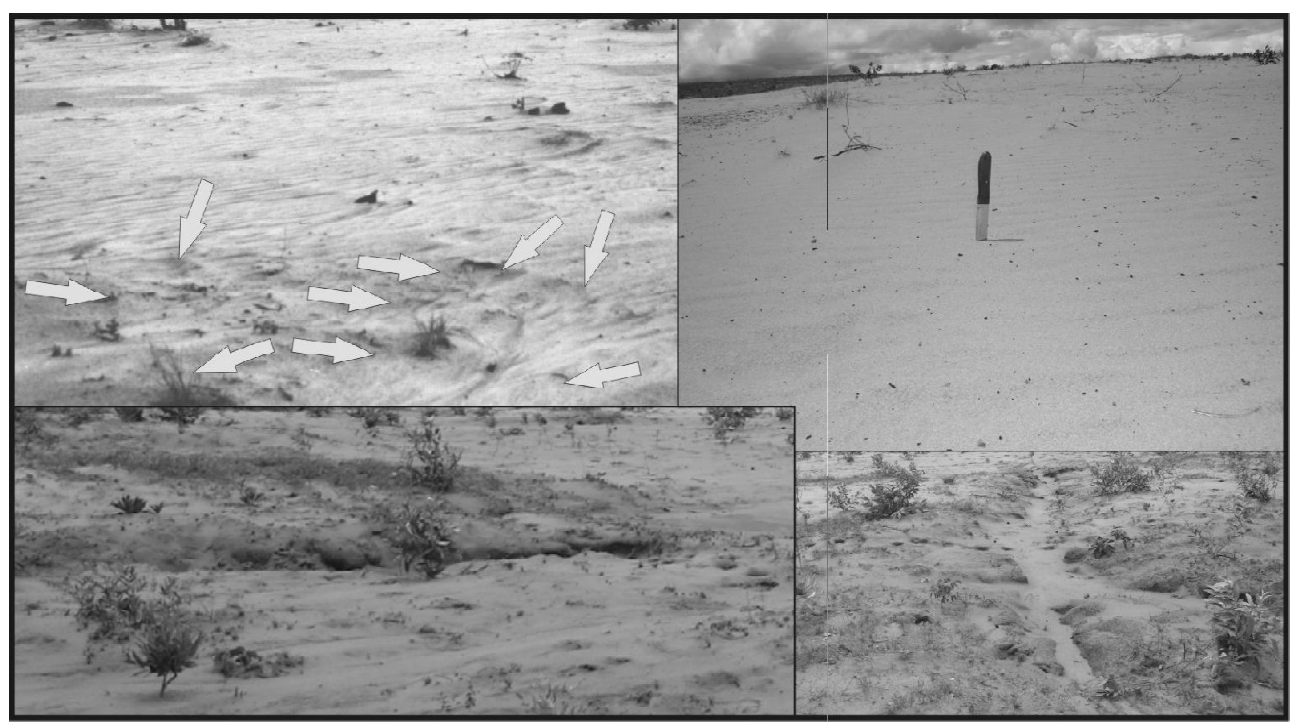

(Fotos: 05/12/2005 e 16/12/2006).

Na Figura 8, compara-se uma incisão erosiva no período chuvoso: A) em janeiro de 2003 e B) no período seco, em julho de 2006. Verifica-se que, em três anos e meio, houve tendência à diminuição da ravina. Além disso, a dinâmica geomórfica tende a verticalizar o processo no período chuvoso, aprofundando a erosão, enquanto no período seco há tendência ao seu alargamento pela erosão lateral e colmatagem no centro da ravina. A sucessão desta dinâmica nos dois períodos do ano promove a constante mobilização de sedimentos, o que contribui para dificultar a fixação da vegetação e, portanto, atua na evolução do areal.

Figura 8 - Areal nos períodos chuvoso e seco, em janeiro de 2003 (A) e em julho de 2006 (B) (Areal 4)

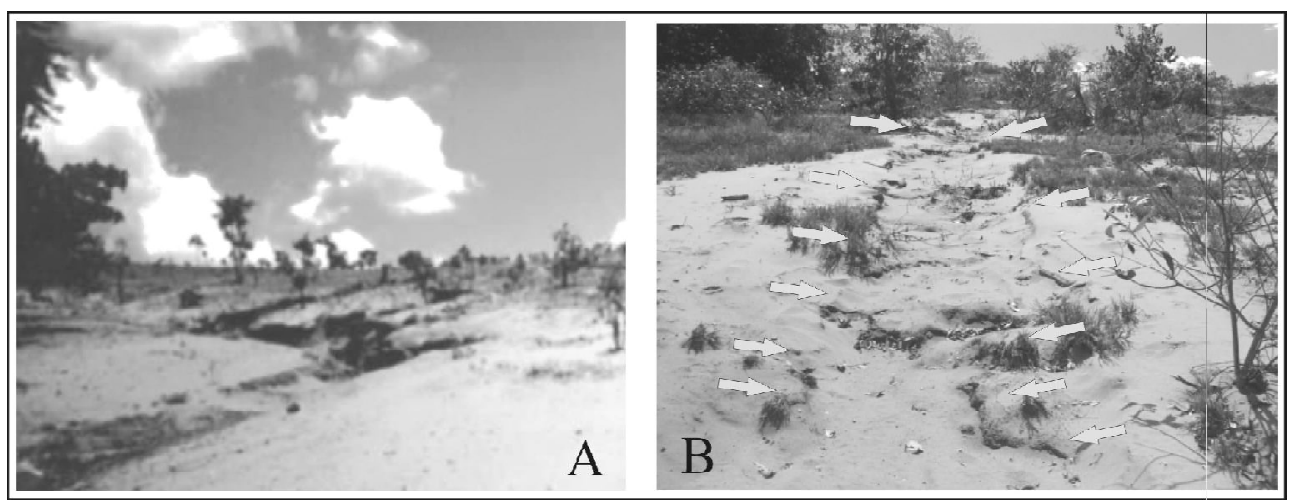

(Foto 1/Neuder Lima: Jan/2003 e Foto 2: 04/08/2006). 
Outro aspecto a considerar, refere-se à presença de uma camada de areia solta, com transição abrupta e descontínua sobre o Ap, de cor mais clara que, provavelmente, se deve à menor umidade e ao baixo teor de MOS. Esta camada, que pode ser observada na Figura 9, ainda que bastante comum, não ocorre em todos os trechos dos areais.

Figura 9 - Camada superficial de areia mobilizada e esbranquiçada no Areal 1

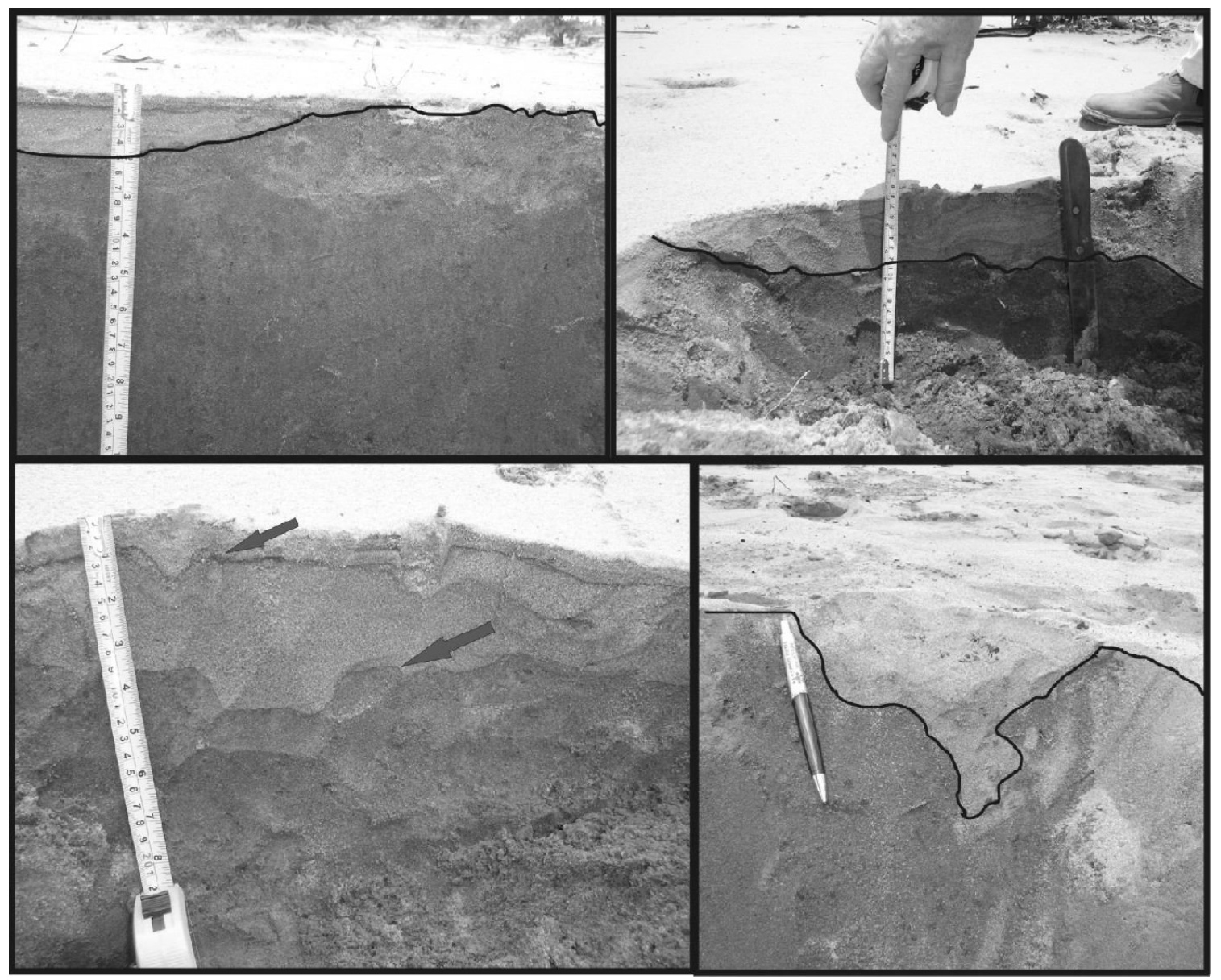

(Fotos: 16/12/2006).

A maior espessura encontrada no Areal 1 , cerca de $12 \mathrm{~cm}$, posiciona-se sobre antiga estrada para o transporte da cana-de-açúcar, sugerindo que a camada possa ser resultante do preenchimento de pequenas depressões no terreno, tal como já observara A. da Silva (2006). Neste sentido, os sulcos abertos durante
- plantio da cana, as marcas de patas do gado (Figura 10) e sulcos de erosão tendem a ser colmatados, dada a facilidade de transporte e deposição da areia fina, predominante na textura desse areal, e à atuação constante das águas pluviais e do vento, originando esta camada. 


\section{Figura 10 - Sulcos existentes na plantação de cana (área de plantio da Energética Serranópolis) e do pisoteio do gado (Areal 1)}

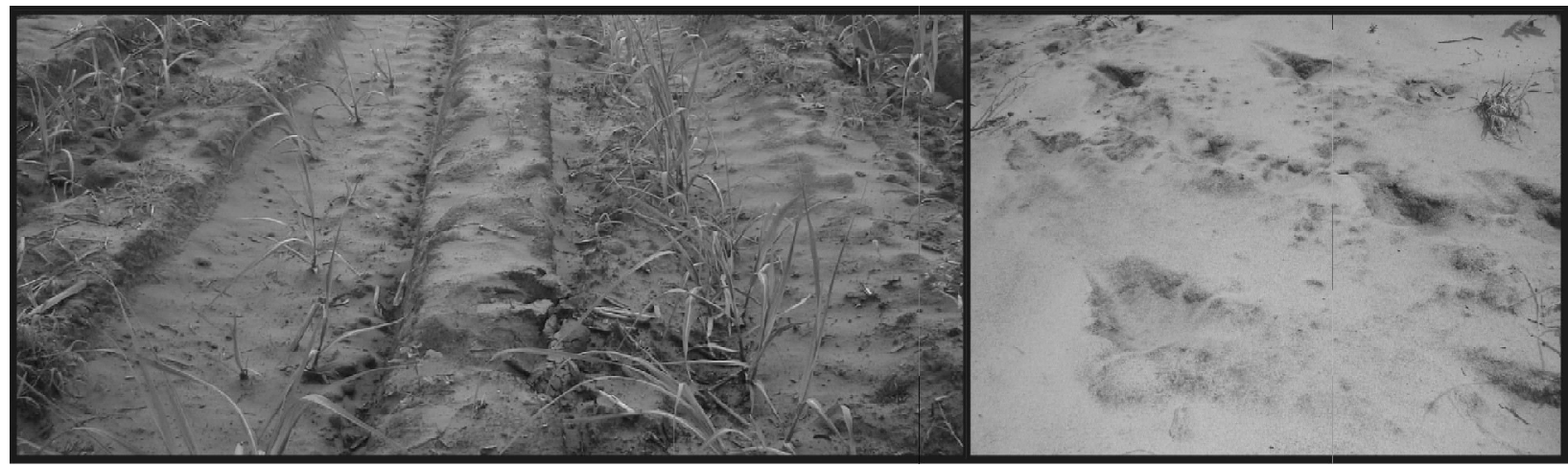

(Fotos: $16 / 12 / 2006)$

Todavia, observou-se que, por vezes, a camada de areia solta aparece no terço superior da vertente, indicando que ela é resultante da simples mobilização da areia em superfície, processo bastante comum devido às atividades que ali já se desenvolveram, como gradagens e pisoteio do gado.

\section{Conclusões: Areais: marcas de um processo}

Da Figura 11 consta o organograma que ilustra a sequência da formação de areais, tal como foi analisada em trabalho anterior (SOUSA, 2007). Ressalta-se que a metodologia para a análise do processo de formação de areais está calcada na categoria paisagem. Foram analisados os elementos físico/ecológicos da paisagem, que são os condicionantes naturais, bem como suas potencialidades e limitações, verificando-se que as áreas de ocorrência dos areais têm forte fragilidade potencial. Posteriormente descreveuse as transformações da paisagem pelos processos sociais, no âmbito da modernização da agricultura, enfatizando o plantio da canade-açúcar, seguido pelo de pastagem, ambos com manejo inadequado. Este processo, que reúne a fragilidade potencial com o manejo inadequado resultou no processo de degradação ambiental, evidenciado no solo e na vegetação pela ocorrência dos areais. Este artigo abrange a última fase desta pesquisa, isto é, que estuda como todos estes fatores físico/ecológicos e sociais, em conjunto, resultam na degradação do solo e na formação dos areais.

Os estudos, até o momento, indicam que os areais resultam de processos de degradação do solo, instaurados por práticas inadequadas de utilização e manejo da terra. Caracterizam-se como feições ou marcas de um processo socioeconômico que ignora as potencialidades e fragilidades dos elementos físico/ecológicos da paisagem.

Em suma, o processo de formação de areais envolve uma dinâmica que se desencadeou a partir do manejo inadequado do solo numa área de forte fragilidade potencial, originando pequenas manchas de areia exposta onde as sementes de pastagem não germinaram ou morreram, manchas que foram submetidas à erosão hídrica e eólica e à lixiviação de nutrientes e perda de matéria orgânica, esta essencial no sistema natural. Os fatores em conjunto foram, ainda, potencializados pela continuidade do manejo inadequado, visto que as áreas continuaram sendo utilizadas com pecuária até cerca de quatro anos atrás (2004). As características intrínsecas dos Neossolos Quartzarênicos favorecem a degradação, que 


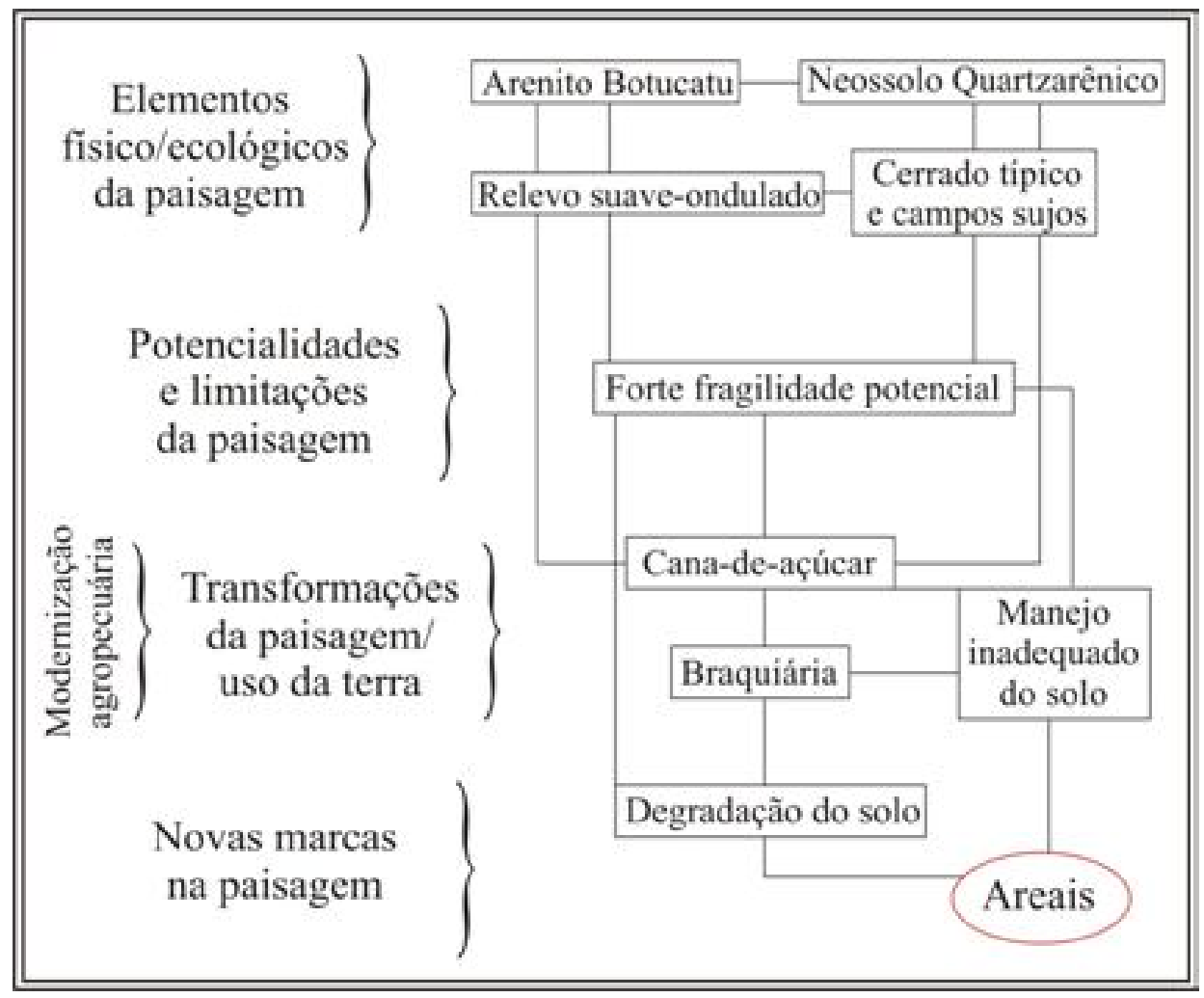

Figura 11 - Síntese do processo de formação de areais na bacia do Ribeirão Sujo.

ficou evidenciada pela perda por completo da já muito fraca estrutura natural na camada superficial o que, por sua vez, repercute na deficiência de nutrientes e matéria orgânica e na baixa capacidade de retenção de água, fatores, dentre outros, que facilitaram a expansão dos areais.

É interessante observar que a formação de areais parece ultrapassar os limites da degradação do solo, pois inclui a degradação das pastagens, a erosão, o assoreamento, a alteração no ciclo hidrológico, etc., envolvendo um processo mais amplo, que poderia ser relacionado à degradação ambiental, cuja definição apresenta vasta literatura. Embora todos estes fatores tenham sido também apresentados ao longo do trabalho, foi destacada a análise da degradação do solo porque seu estudo já abrange múltiplas variáveis.

\section{Notas}

${ }^{1}$ Texto baseado no capítulo 5 da dissertação da autora, defendida em 2007, no Programa de PósGraduação em Geografia do IESA/UFG. Artigo elaborado em maio de 2008.
2O termo "manchas de areia" é utilizado como sinônimo de "areais" ou ainda, dentro do contexto, entendido como uma área mais ampla que apresenta vários areais separados por áreas com vegetação rala. 


\section{Referências Bibliográficas}

A. DA SILVA, R. A. Arenização/desertificação no setor sul da alta Bacia do Rio Araguaia (GO/ $M T)$ : distribuição e fatores condicionantes de formação dos areais. 2006. 136 f. Dissertação (Mestrado em Geografia) - Instituto de Estudos Sócio-ambientais. Universidade Federal de Goiás, 2006.

BERTONI; J.; LOMBARDI NETO, F. Conservação do solo. 4. ed. São Paulo: Ícone, 1999, 355 p. CBERS. Imagem de satélite. São José dos Campos: Instituo Nacional de Pesquisas Espaciais, 2006. Resolução 20 metros. Canais 2, 3, 4.

DIAS, L. E; GRIFFITH, J. J. Conceituação e caracterização de áreas degradadas. In: DIAS, L. E; MELLO, J. W. V. de (Eds.) Recuperação de áreas degradadas. 20. ed. Viçosa: UFV, Departamento de solos; Sociedade Brasileira de Recuperação de Áreas Degradadas, 1998. p. 1-7.

DOORENBOS, J. KASSAN, A. H. Efeito da água no rendimento das culturas. Tradução de HR. Gheyi et al. Campina Grande: UFPB, 1994. $306 \mathrm{p}$.

EMBRAPA/CNPS. Manual de Métodos de Análise de Solo. Rio de Janeiro: CNPS, 1997.

FERRI, M. Ecologia dos cerrados. In: SIMPÓsIO SOBRE O CERRADO, 4, 1976. Brasília. Belo Horizonte: Itatiaia; São Paulo: USP, 1977. P. 1536.

IBGE, Carta Topográfica SE 22 Y B IV, Folha Ribeirão da Pedra. Rio de Janeiro, 1977. Escala $1: 100000$.

LEPSCH, I. F. Formação e conservação dos solos. São Paulo: Oficina de Textos, 2002.

MENDES, J. C. Elementos de estratigrafia. São Paulo: T.A. Queiroz, 1984.

OliVeirA, M. A. T. de. Processos erosivos e preservação de áreas de risco de erosão por voçorocas. In: GUERRA, A. J. T; SILVA, A. S. da;
BOTELHO, R. G. M. (Orgs.) Erosão e conservação dos solos: conceitos, temas e aplicações. Rio de Janeiro: Bertrand Brasil, 1999.

PASQUALETTO, A.; ZITO, R. K. Impactos ambientais da monocultura da cana-de-açúcar. 1 ed. Goiânia: EDUFG, 2002.

PETRI, S.; FÚLFARO, V. J. Geologia do Brasil. Ed. São Paulo: EDUSP, 1983.

REINERT, D. J. Recuperação de solos em sistemas agropastoris. In: DIAS, L. E; MELLO, J. W. V. de (Editores) Recuperação de áreas degradadas. 20. ed. Viçosa: UFV, Departamento de solos; Sociedade Brasileira de Recuperação de Áreas Degradadas, 1998. P. 163-176.

RESENDE, M. et al. Pedologia: base para distinção de ambientes. 3a ed. Viçosa: UFV/ NEPUT, 2002.

ROSCOE, R. Dinâmica da Matéria Orgânica em solos de Cerrado. In: CONGRESSO BRASILEIRO DE CIÊNCIA DO SOLO, 30., 2005. Recife. Palestra..., Recife: UFPE/SBCS, 2005. CD-ROM.

ROSS, J. L. S. Análise empírica da fragilidade dos ambientes naturais e antropizados. Revista do Departamento de Geografia, São Paulo, USP, n.8, p.63-74, 1994.

SCOPEL, I.; PEIXINHO, D. M.; SOUSA, M. S. A formação de areais e seu controle na região de Jataí e Serranópolis/GO. Relatório final do Projeto. Jataí/GO: PROINPE/SECTEC-GO, 2005. $155 \mathrm{f}$.

SOUSA, M. M. As transformações da paisagem: contribuição ao estudo da formação de areais na bacia do Ribeirão Sujo, município de Serranópolis/GO. 2007. 205 f. Dissertação (Mestrado em Geografia) - Instituto de Estudos Sócio-ambientais. Universidade Federal de Goiás, 2007. 
SPERA, S. T., et al. Solos areno-quartzosos no Cerrado: problemas, características e limitações ao uso. Planaltina/DF: Embrapa Cerrados, 1999. 48p. (Documentos n.7).

SUERTEGARAY, D. M. A. Desertificação: recuperação e desenvolvimento sustentável. In: GUERRA， A. J. T.; CUNHA, S. B (org.)
Geomorfologia e Meio Ambiente. Rio de Janeiro: Bertrand Brasil, 1996, p. 249-289.

USAF/UNITED STATES AIR FORCE. Fotografias aéreas $\mathrm{n}^{\mathrm{os}}$. 34754, 34755, $34756,34757,34801,34802,34803$, 34804, 35723, 35724, 35725 e 35726.1965. Escala: 1:60000.

Trabalho enviado em Maio de 2008 Trabalho aceito em Novembro de 2008 
